\title{
Sistem Deteksi Biometrik Keunikan Wajah Secara Real Time
}

\author{
Anita Sindar Ros Maryana Sinaga ${ }^{1 *}$, Arjon Samuel Sitio ${ }^{1}$ \\ 1Program Studi S1 Teknik Informatika, STMIK Pelita Nusantara \\ *Email: haito_ita@yahoo.com
}

\section{Info Artikel}

Kata Kunci :

biometrik, deteksi wajah, real time, kotak seleksi wajah

\section{Keywords :}

biometrics, face detection, real time, face selection box

\section{Tanggal Artikel}

Dikirim : 12 November 2019

Direvisi : 14 November 2019

Diterima : 15 November 2019

\begin{abstract}
Abstrak
Pengenalan wajah penting untuk mengidentifikasi biodata profil seseorang. Perkembangan fsik mahasiswa sejak masuk perkuliahan hingga lulus mengalami perubahan yang tidak mencolok tetapi terkadang sulit mengidentifikasi wajah satu per satu. Bentuk digital menjadi trend mengingat lebih real time. Bagian penting dari fisik manusia sebagai identifikasi mulai bergeser dari tandatangan - finger - seleksi wajah. Wajah meliputi lima indra penting yang saling berhubungan menjadi alat pengenal. Dalam penelitian ini fokus pada deteksi wajah berdasarkan warna, penerapan Algoritma Camshift dan menemukan jarak antara titik-titik indra wajah merupakan hasil metode Gabor Wavelet. Data training menggunakan video real time berdurasi 4-8 detik. Histogram hue pada dasarnya sama dengan histogram RGB bedanya pada histogram hue menggunakan nilai Hue sebagai ganti dari RGB karena nilai hue menyatakan warna alami tanpa memperhatikan pencahayaan. Transformasi Gabor Wavelet disediakan untuk menyelesaikan permasalahan desain filter. Sistem deteksi wajah mencari titik-titik wajah membentuk seleksi wajah berbentuk frame apabila sebelumnya wajah sudah tersimpan dalam database maka dengan mudah sistem mendeskripsikan biodata. Seleksi wajah dapat dilakukan pada data testing secara live. Pendeteksian kotak seleksi mengikuti setiap gerakan wajah.
\end{abstract}

\section{Abstract}

Facial recognition is important for identifying a person's biodata profile. The physical development of students from the time they entered college to graduation has experienced inconspicuous changes but it is sometimes difficult to identify faces one by one. Digital form is becoming a trend to remember more real time. An important part of human physical identification has begun to shift from signature - finger - face selection. The face includes five important senses that are interconnected into an identification device. In this study the focus is on face detection based on color, the application of the Camshift Algorithm and finding the distance between the face sensing points is the result of the Gabor Wavelet method. Training data uses 4-8 second real time video. The hue histogram is basically the same as the RGB histogram, the difference is that the hue histogram uses the Hue value instead of RGB because the hue value represents natural color without regard to lighting. Gabor Wavelet transform is provided to solve filter design problems. The face detection system looks for face points to form a frame-shaped face selection if previously the face has been stored in a database so the system can easily describe biodata. Face selection can be done on live testing data. The selection box detection follows every facial movement. 


\section{PENDAHULUAN}

Teknologi biometrik dirancang khusus mengenal sifat karakteristik sisi biologis manusia memungkinkan sistem dapat mengidentifikasi mengenal dan menangkap objek dalam layar digital. Teknologi biometrik mendeteksi autentikasi secara biologis memungkinkan sistem tepat mengidentifikasi objek yang diam maupun bergerak. Beberapa sistem yang dikembangkan seperti fingerprint scanning, retina scanning, dan DNA scanning. Fingerprint scanning saat ini telah digunakan secara luas dan digunakan bersama-sama untuk absensi kehadiran [1]. Teknik biometrik dianggap efektif mampu mengidentifikasi wajah dari jarak jauh. Di dalam studi pengolahan citra dan pengenalan pola, feature space adalah ruang abstrak di dalam citra setiap contoh pola digambarkan sebagai sebuah titik di dalam ruang dimensi $n$ atau n-dimensional space. Beberapa metode identifikasi wajah yang populer Algoritma CAMshift, Metode Gabor Wavelet dan Algoritma Viola Jonas. Sensor wajah pada sistem bekerja dengan memanfaatkan ekstraksi ciri dengan metode gabor wavelet [2]. Gabor Wavelet memunculkan ciri-ciri khusus dari citra yang telah dikonvolusi terhadap kernel. Autentifikasi wajah pada algoritma CAMshift menerapkan model warna HSV. Model warna HSV diturunkan dari model warna RGB maka untuk mendapatkan warna HSV, proses konversi warna dari RGB ke HSV. Nilai hue menyatakan warna dominan kulit. Histogram hue menggunakan nilai hue sebagai dasar perpaduan RGB [3]. Model Gabor Wavelet mendapatkan ciri wajah dengan mendapatkan nilai frekuensi spasial, wilayah spasial, dan orientasi selektivitas. Proses manipulasi citra Konvolusi (convolution) menggunakan eksternal mask /subwindows untuk menghasilkan citra yang baru [4]. Detektor wajah yang dipublikasikan Paul Viola dan Michael Jones dikenal metoda Viola-Jones. gelombang tunggal bujur sangkar (satu interval tinggi dan satu interval rendah). Proses perancangan sistem dimulai dengan pengambilan video secara real time. Video berdurasi 4-8 detik ditracking untuk memisahkan objek dengan warna background. Algoritma Meanshift mencari posisi wajah berdasarkan warna Hue. Penelitian sebelumnya terdapat kelemahan algoritma CamShift yaitu setiap warna yang terdeteksi diidentifikasi satu warna dengan warna background. untuk mengatasi hal tersebut pada algoritma CamShift ditambahkan proses dilatasi [5]. Dengan teknik Gabor Wavelet, komputer menyerupai otak manusia dalam berbagai tugas pengenalan wajah yang luas bertujuan memunculkan ciri-ciri khusus dari citra yang telah dikonvolusi [6].

\section{METODE PENELITIAN}

Biometriks secara teoritis mengukur karakteristik masing-masing pribadi untuk membedakan setiap orang [7]. Mekanisme sistem biometrik digambarkan dengan beberapa fase 1) Fase Penggolongan, masukan dipindai (scan) oleh sensor biometrik, yang merupakan representasi karakteristik digital 2) Fase Pencocokan, nputan database akan dicocokkan dengan identifikasi data. Dapat dimungkinkan adanya reduksi, sehingga dihasilkan representasi digital. 3) Fase Pengenalan, karakteristik individu dibaca oleh pembaca biometrik (reader). Recognition aplikasi desktop yang menggunakan wajah sebagai autentikasinya atau pengenalan dan identifikasi wajah otomatis [8]. Transformasi wavelet dikembangkan menggunakan wavelet Gabor seperti fungsi dasar untuk membuat ekspansi sinyal nonstasioner $f(x, y)$ dalam hal atom frekuensi-waktu [9]. Konvolusi diperoleh dari perkalian total fungsi $f$ dan $h$ [10]: $f * h=\int_{0}^{T} f t(h) T-t(h) d t$

Filter pada citra pada bidang spasial menggunakan konvolusi dari (I) dan fungsi filternya $(\mathrm{H}) ; \mathrm{m}, \mathrm{n}=$ ukuran dari fungsi filter dalam matrik [11]:

$$
I^{\prime}(x, y)=\sum_{i=n}^{n} \sum_{j-m}^{m} h(i, j)(x+i),(y+j)
$$

Jika Gabor filter dengan variasi frekuensi (f) dan orientasi $(\theta)$ diterapkan pada titik tertentu $(\mathrm{x}, \mathrm{y})$, maka didapatkan banyak respon filter untuk titik. Citra database dan citra yang akan dikenali dikonvolusi lebih dahulu dengan Gabor Filter [12], [13]. Tahapan metode penelitian :

a. Sumber data penelitian diperoleh dari data video real time.

b. Subjek penelitian, citra berbentuk video real time format mp4.

c. Objek penelitian fokus pada biometrik wajah.

d. Populasi dan sampel penelitian. Ada beberapa jenis format video dan gambar dalam citra, jpeg (joint photographic experts group), bmp (bitmap picture),gif (graphic interchange format), png (portable network graphic) ,tiff (tagged image file format).

5. Analisa dan perancangan, menganalisa cara untuk mendeteksi pada bagian biometrik wajah dengan Algoritma Meanshift, Algoritma Camshift Dan Metode Gabor Wavelet. 
6. Menerapkan algoritma, penerapan penggunaan algoritma dan metode yang menghasilkan deteksi biometrik wajah.

7. Menguji hasil. Tahapan review terhadap hasil sistem yang dirancang. Input citra digital diambil dari video real time dikonversi menjadi format avi agar dapat ditracking, memisahkan data set dengan warna latar belakang. Tahapan seleksi biometrik wajah Gambar 1.

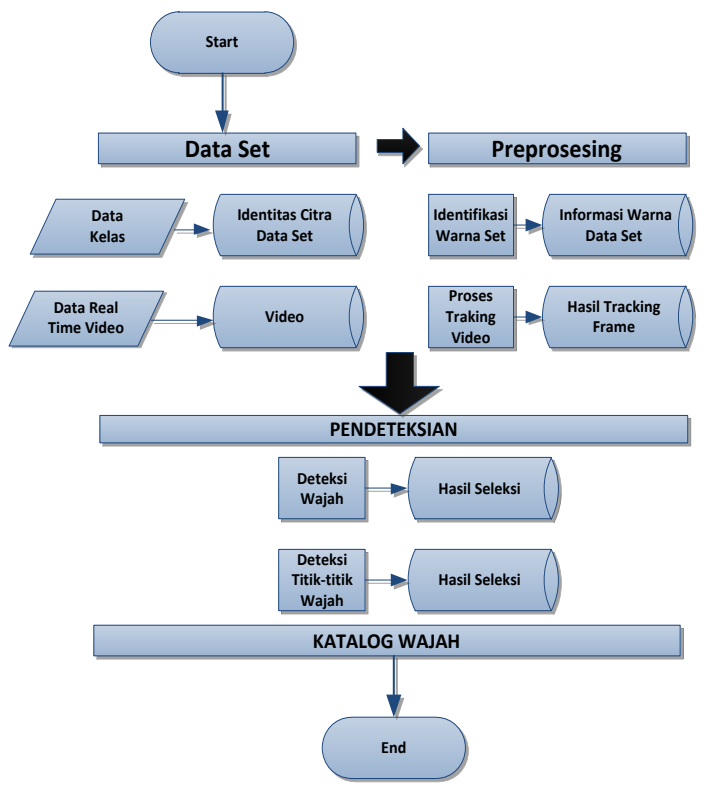

Gambar1. Tahapan Penelitian

\section{HASIL DAN PEMBAHASAN}

Ekstraksi ciri citra dilakukan dengan operasi konvolusi citra aras keabuan dengan tapis yang terbentuk. Metode Gabor merupakan teknik analisis sinyal dikawasan gabungan spasial dan waktu yang mampu mendeteksi spektrum informasi sinyal non-stasioner yang berubah terhadap waktu. Untuk dua dimensi, satu terang dan satu gelap. Pendekatan untuk mendeteksi objek dalam gambar menggabungkan konsep utama yaitu 1) fitur segi empat sederhana 2) integral image untuk pendeteksian fitur 3) metoda machine learning 4) klasifier bertingkat untuk menghubungkan banyak fitur secara efisien. Region of Interest (ROI) pada openCV adalah sebuah area persegi dalam suatu gambar, untuk membagi suatu objek berdasarkan segmen yang dikehendaki untuk pemrosesan selanjutnya. Video diambil secara live di dalam ruangan durasi 5-8 detik dengan posisi menghadap video camera. Data video, Lebar Frame 856 Tinggi Frame 480. Menu File terdapat 3 sub menu antara lain File List Class dan File List Movie. Tampilan Form Data Kelas menapilkan data mahasiswa yang masih aktif.
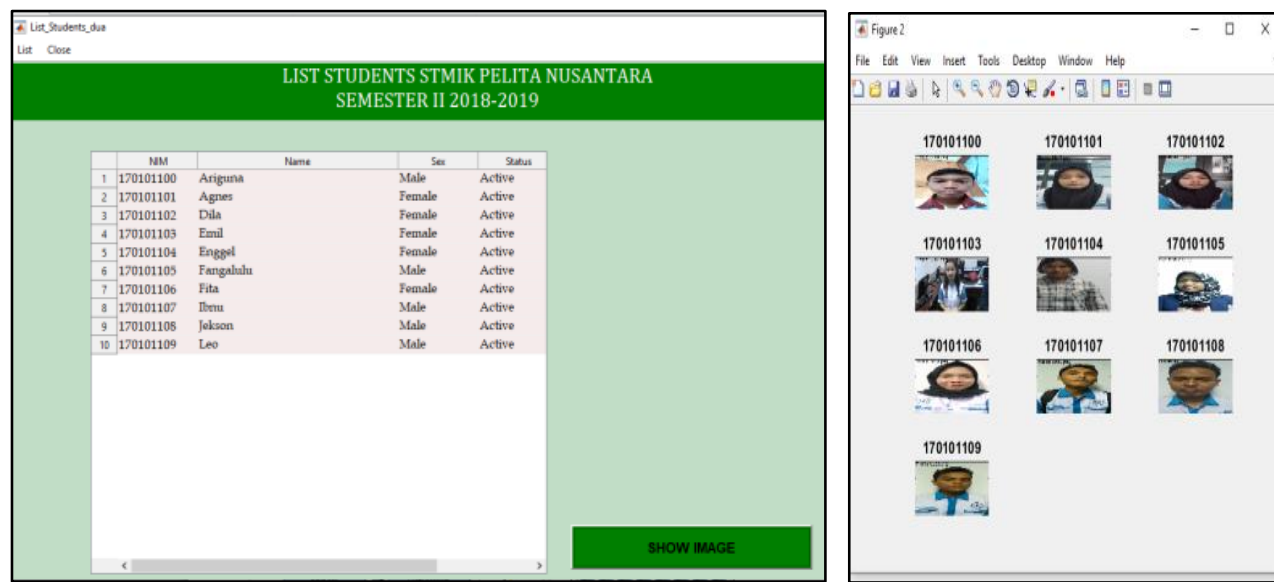

Gambar 2. Tampilan Data Set 
Jumlah warna untuk citra RGB diperoleh dengan mengalikan jumlah masing-masing komponen, jumlah dari tiap komponennya, $R=255$ (8bit). $G=255$ (8bit) dan $B=255$ ( $8 \mathrm{bit}$ ) yang sering disebut sebagai citra dengan intensitas 24 bit atau true color. Sehingga jumlah byte yang diperlukan untuk file citra RGB lebih 3 kali space file grayscale. Setiap piksel dari citra grayscale 256 gradasi warna diwakili oleh 1 byte dan 1 piksel citra RGB diwakili oleh 3 byte, masingmasing byte merepresentasikan warna Red, Green, Blue didalam memori. Citra RGB dapat diubah menjadi citra Grayscale dengan cara menghitung rata-rata elemen warna Red, Green, Blue $f_{0}=(x, y)=\frac{f_{i}^{R}(x, y)+f_{i}^{G}(x, y)+f_{i}^{B}(x, y)}{3}$

Bila setiap proses perhitungan dilakukan menggunakan tiga layer, berarti dilakukan tiga perhitungan yang sama. Sehingga konsep itu diubah dengan mengubah 3 layer menjadi 1 layer matrik gray-scale dan hasilnya adalah citra grayscale. Teknik perataan histogram merupakan gabung antara penggeseran dan pelebaran histogram. Perataan histogram ini mentransformasi tingkat keabuan rk menjadi sk dengan suatu fungsi transformasi T (rk). Fungsi transformasi memiliki syarat $T(r)$ memberikan nilai tunggal sehingga memiliki inverse serta monoton naik untuk interval $0 \leq r \leq 1$; $0 \leq T(r) \leq 1$ untuk $0 \leq r \leq 1$.

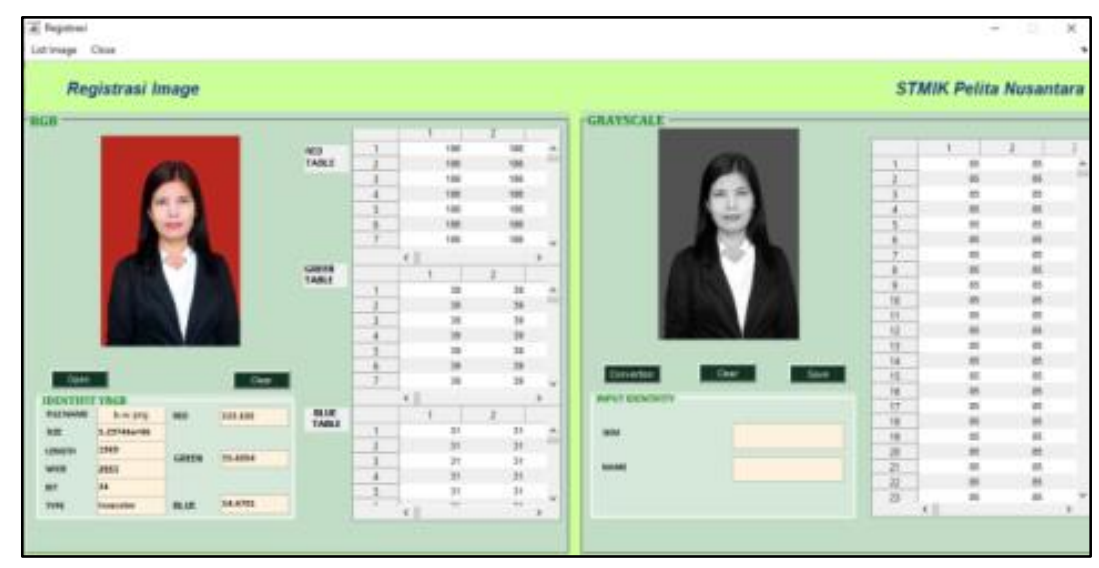

Gambar 3. Konversi Warna

Citra dalam model RGB terdiri dari tiga bidang citra yang saling lepas, masing-masing terdiri dari warna utama merah (Red) hijau (Green) dan biru (Blue). Citra mengandung nilai grayscale yaitu derajat putih menuju hitam, Gambar 4.
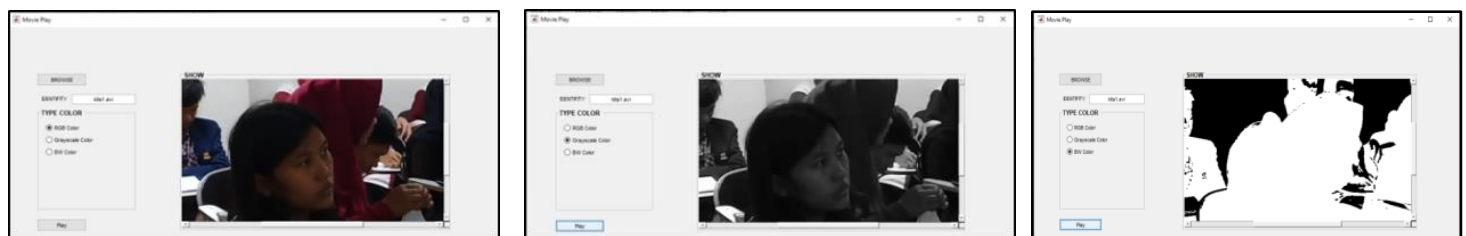

Gambar 4. Tampilan Real Time Video Data Set

Sistem analisis membedakan garis, pori-pori, dan tekstur wajah yang aktual, hingga dapat membedakan kembar identik sekalipun. Data disimpan untuk dikonfirmasi dengan input data yang ingin dicocokkan. Proses identifikasi wajah menggunakan coding Matlab didukung openCV. Langkah 1: Deteksi Wajah untuk Dilacak. Sebelum mulai melacak wajah, terlebih dahulu mendeteksinya. Gunakan visi.CascadeObjectDetector untuk mendeteksi lokasi wajah dalam bingkai video. Langkah 2: Identifikasi Fitur Wajah untuk Dilacak. Setelah wajah ditemukan dalam video, langkah selanjutnya adalah mengidentifikasi fitur yang akan membantu melacak wajah. Misalnya menggunakan bentuk, tekstur, atau warna. Pilih fitur yang unik untuk objek dan tetap invariant bahkan ketika objek bergerak. Langkah 3: Lacak Wajah. Warna kulit dipilih sebagai fitur untuk dilacak, sekarang dapat menggunakan vision. Pelacak berbasis histogram menggunakan algoritma CAMShift, kemampuan untuk melacak objek menggunakan histogram nilai piksel. Piksel saluran Hue diekstraksi dari daerah hidung wajah yang terdeteksi, Gambar 5. 

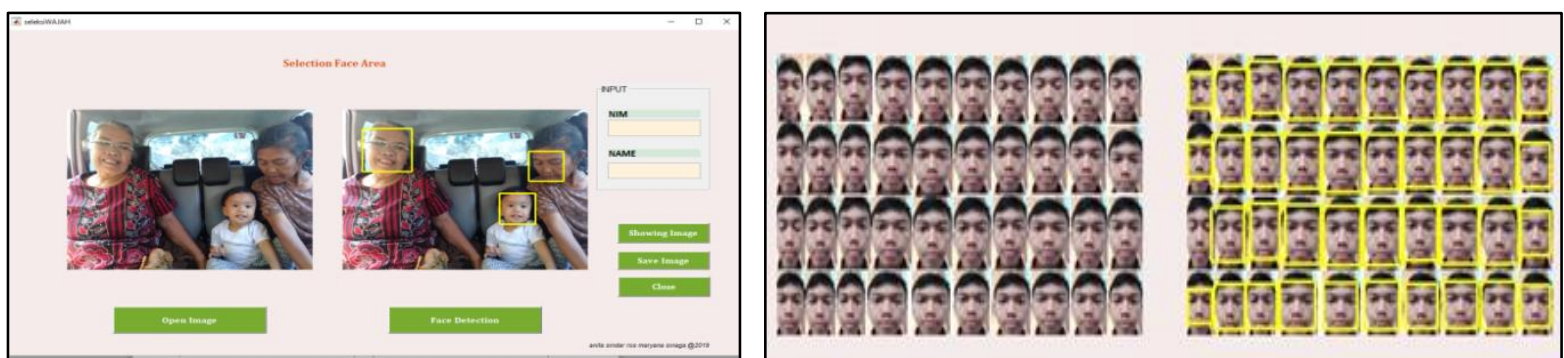

Gambar 5. Hasil Seleksi Wajah

Seleksi wajah terhadap bagian mulut, mata kanan, mata kiri dan hidung. Diperoleh jarak antara mata kanan - mata kiri, hidung - mata kanan, hidung - mata kiri, hidung - mulut, Gambar 6.
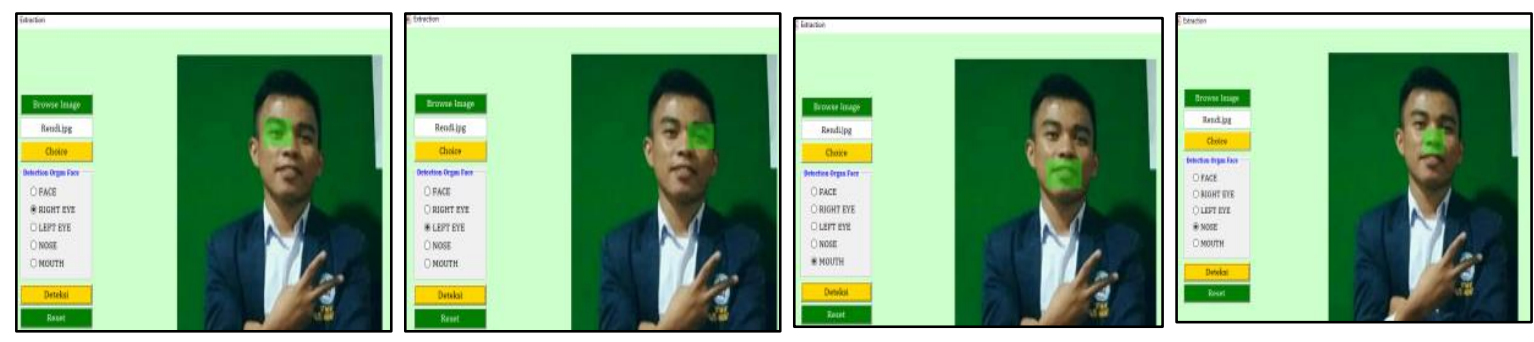

Gambar 6. Seleksi Bagian Biometrik

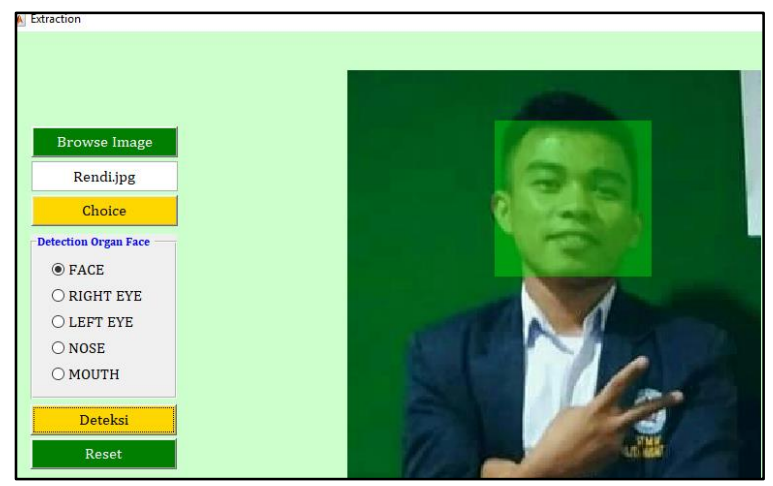

Gambar 7. Seleksi Area Wajah

\section{KESIMPULAN}

Kesimpulan dari hasil dan pembahasan penelitian yaitu seleksi wajah berbentuk kotak segi empat (bounding box) berhasil mendeteksi warna kulit bagian wajah model warna Hue. Posisi data set terseleksi bila menghadap camera deteksi. Hasil penghitungan jarak antara biometrik wajah menjadi ciri unik yang dapat disimpan dalam database kemahasiswaan. Sistem deteksi wajah yang dihasilkan dapat diterapkan dengan mudah pada ruangan pembelajaran kampus baik untuk absensi atau monitoring keadaan kelas. Hasil pengembangan rancangan seleksi wajah untuk format live (real time) memungkinkan deteksi wajah lebih akurat setelah melalui proses preprosesing data. Seleksi wajah dengan menggunakan bermacam-macam metode mempunyai kelebihan dan kekurangan didukung oleh sumber data yang bergantung pada pencahayaan dan posisi objek citra.

\section{UCAPAN TERIMA KASIH}

Penelitian ini terlaksana sesuai pengajuan proposal PDP tahun 2018, pelaksanaan penelitian tahun 2019, dengan Nomor Kontrak Nomor: 043/STMIK-LPPM/N/2019. Peneliti mengucapkan terima kasih sebesar-besarnya pada DIKTI. 


\section{DAFTAR PUSTAKA}

[1] Sultoni, Hary Soekotjo Dachlan, Panca Mudjirahardjo, Rahmadwati, "Pengenalan Wajah Secarareal Time Menggunakan Metode Camshift, Lapalcian Of Gaussian Dan Discrete Cosine Transform Two Dimensional (LoGDCT2D)", Jurnal IImiah NERO Vol. 2, No.3 hal : 153-160, tahun 2016.

[2] Luki Wahyu Hendrawan, Mohammad Ramdhani, Dadan Nur Ramadan, "Rancang Bangun Sistem Pelacakan Objek Secara Real Time Berdasarkan Warna", e-Proceeding of Applied Science : Vol.2, No.1 pp: 383-388, April 2016.

[3] Naser Jawas, "Pelacakan Gerakan Tangan Untuk Pengenalan Gerak-Isyarat", IT Journal, Vol. 5 No. 1, hal 1323, April 2017.

[4] Romi Wiryadinata, Raya Sagita, Siswo Wardoyo, Priswanto, "Pengenalan Wajah Pada Sistem Presensi Menggunakan Metode Dynamic Times Wrapping, Principal Component Analysis dan Gabor Wavelet", Dinamika Rekayasa, vol 12, hal 1-8, Tahun 2016.

[5] Adil Setiawan, "Penerapan Algoritma Gabor Wavelet Sebagai Keamanan Rumah Dengan Mengidentifikasi Wajah Berbasis Webcam", Eksplora Informatika Vol. 5, No. 2, Maret 2016.

[6] Andre Lukito Kurniawan, R. Rizal Isnanto, Ajub Ajulian Zahra, "Perancangan Sistem Pengenalan Wajah Menggunakan Metode Ekstraksi Ciri Susunan Tapis Wavelet Gabor 2D Dengan Jarak Euclidean", TRANSIENT, vol 4, hal 2-5, 2015.

[7] Aris Budi, Suma'inna, Hata Maulana, "Pengenalan Citra Wajah Sebagai Identifier Menggunakan Metode Principal Component Analysis (PCA)", JURNAL TEKNIK INFORMATIKA, vol 9, hal 166-175, Tahun 2016.

[8]. Sultoni, "Modifikasi Metode Camshift Untuk Pengenalan Citra Wajah Secara Real Time Berdasarkan Warna Kulit Wajah", Seminar Nasional Inovasi Dan Aplikasi Teknologi di Industri 2017, hal 1-7, 2017.

[9]. Jefry Sunupurwa Asri, Gerry Firmansyah, "Implementasi objek detection dan tracking menggunakan deep learning untuk pengolahan citra digital”. Konferensi Nasional Sistem Informasi 2018, STMIK Atma Luhur Pangkalpinang, 8 - 9, hal : 717-723, Maret 2018..

[10] Andrean Hutama Koosasi, Riyanarto Sarno, dan Abdul Munif, "Deteksi Fraud Menggunakan Metode Model Markov Tersembunyi pada Proses Bisnis", JURNAL TEKNIK ITS Vol. 6, hal 1-5, Tahun 2017.

[11] Immanuela P. Saputro, Ernawati, B.Yudi Dwiandiyanta, "Pengenalan Ekspresi Wajah Menggunakan Wavelet Gabor Dan Backpropagation", JURNAL ELEKTRO, Vol. 8, hal 71-78, Tahun 2015.

[12] Anita Sindar RM Sinaga, Implementasi Teknik Thresholding Pada Segmentasi Citra Digital, Jurnal Mantik Penusa, Vol 1 No. 2 hal. 48-51, 2017.

[13] Untari Novia Wisesty, Titik Mutiah, "Implementasi Gabor Wavelet dan Support Vector Machine pada Deteksi Polycystic Ovary (PCO) Berdasarkan Citra Ultrasonografi", Ind. Journal on Computing, Vol. 1, Issue. 2, Sept 2016. pp. 67-82, tahun 2016. 